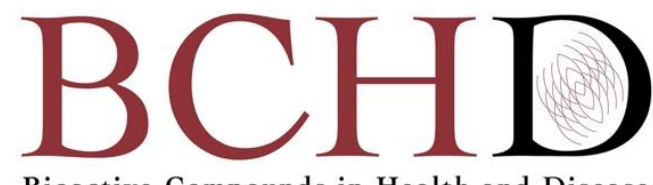

Bioactive Compounds in Health and Disease

\title{
Using graphics to promote the health values of indigenous vegetables in anemia, metabolic syndrome, and wound management
}

\author{
Isaac C. Ishiekwene ${ }^{1}$, Solomon E.O. Egwenu ${ }^{1}$, Helen Chime ${ }^{1}$, Eunice O. Igumbor ${ }^{1}$, \\ Ezekiel U. Nwose ${ }^{1,2^{*}}$
}

\begin{abstract}
${ }^{1}$ Department of Public and Community Health, Novena University Ogume, Nigeria; ${ }^{2}$ School of Community Health, Charles Stuart University, New South Wales, Australia
\end{abstract}

*Corresponding Author: Uba Nwose. School of Community Health, Charles Sturt University, New South Wales, Australia

Submission Date: July 29th 2020 ; Acceptance Date: September $28^{\text {th }}, 2020$; Publication Date: September $30^{\text {th }}, 2020$

Please cite this article as: Ishiekwene I., Egwenu S., Chime H., Igumbor E., Nwose E. Using graphics to promote the health values of indigenous vegetables in Anemia, Metabolic Syndrome and Wound Management. Bioactive Compounds in Health and Disease 2020; 3(9): 166-178. DOI: https://www.doi.org/10.31989/bchd.v3i9.739

\footnotetext{
ABSTRACT

Vegetables are any plant whose fruit, seeds, roots, tubers, bulbs, stems, leaves, or flower parts are used as food. However, this study captures leafy vegetables which are affordable and quick to cook; rich in several macro and micronutrients including vitamins, minerals and fibers which are essential for anemic, metabolic syndrome and wound management. Though the nutritive contents of these vegetables

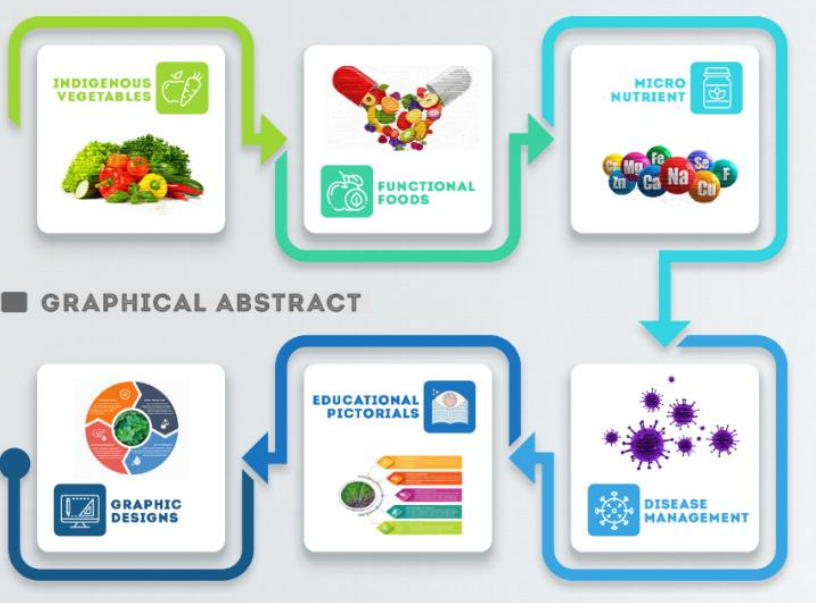
abound, this study aims at advancing the education on the relevant contents of indigenous vegetables based on established data of the synonymous vegetables. This Case Series article was intended to be pictorial
} 
representation of functional leafy vegetables that are available in the research site. Unique graphic designs of the seven indigenous vegetables, which have been previously reviewed, were made to portray their potential micronutrient values and relevance as functional foods in health and disease. Although the seven graphical images indicated similarities, various add-on health values are highlighted. The pictograms depict medical nutrition therapy potentials. . Each pictogram represents an educational tool for health promotion about a vegetable. Bitter leaf had an added value for kidney functions management, Amaranthus for bone maintenance, Lemon grass for insomnia management and general detox, Mint leaf for stomach upset management, Moringa for cancer and malnutrition management, Fluted pumpkin, and Water leaf for constipation management. The health values of these indigenous vegetables include management of common ailments such as anemia, metabolic syndrome and wound management is relatively scarce. This Case Series provides a compendium of seven pictorials to be used as graphical health educational resource to promote consumption of indigenous vegetables in Delta State Nigeria. The significance is to advance health promotion on food matters among a populations where the people may be more inclined to visual prompts. Implications for the COVID19 pandemic is briefly addressed.

Keywords: antioxidants, haematinics, health promotion, immunomodulation, infections, metabolic syndrome, micronutrients, wound management

CFFC 2020. This is an Open Access article distributed under the terms of the Creative Commons Attribution 4.0 License (http://creativecommons.org/licenses/by/4.0)

\section{INTRODUCTION}

Vegetable is often referred to as leafy or soft edible fruits which may be cooked in stew or eaten raw as a salad in Sub-Saharan Africa. Vegetables play an important role in human diet and nutrition as they contain both macro and micronutrients including food fibers, various vitamins such as $A, C$ and $K$; as well as minerals such as iron, potassium, and zinc to human health development. In the published narrative review, evidence-based research used to support the claims in the pictorials have been articulated that:
"So much have been written on leafy vegetables including the African indigenous varieties, but optimum consumption is yet to be achieved. In the previous papers on food choices, it was recommended that some indigenous foods need to be incorporated as alternatives into food menu plans for the intended local population. This paper provides a narrative mini-review of the literature on some leafy vegetables ... to be promoted for their contribution to healthy dietary habit. The nutritional values and traditional medicine usage forms are also briefly highlighted" [1]. 
Thus, the nutritive contents of these vegetables abound, educational graphics on the relevant contents of indigenous vegetables are lacking. Yet, such graphics are essential, especially for displays at community centers and health facilities and billboards. This would contribute as educational tool for health promotion

Objective of study: Broadly, the objective is to advance health education on the relevant contents of indigenous vegetables based on established data of synonymous species. That is, to provide a delineation of unsupported claims about the indigenous vegetables based on similar species that have been studied. Specific objectives are to develop graphics of the potential health values of indigenous vegetables for

1. Anti-anemic minerals

2. Metabolic syndrome: diabetes, hypertension, obesity

3. Wound management

4. Infections - with implication for the ongoing COVID19 pandemic

\section{LIMITATIONS AND SCOPE}

The scope of this piece of work is specifically to develop graphics that depict the potential health values of the series of vegetables. Hence it is a Case Series report. Focused effort is made to provide references to the sources of the claims. This report is limited to potential values with intent to communicate credible information in memorable ways and portray verbal cues; without argumentation semantics or too much scientific jargon that could put off non-scientific audience. There is no speculation of dosing, toxicities, or physiologic mechanisms. However, this is work in progress and as such, comments and suggestions are welcomed on how to add more information without making the pictograph too verbose.

\section{METHODS}

This was designed to be a pictorial representation tool and first stage of the project. Second stage shall be assessment of quality of the tool. In this first stage being reported, graphic designs of indigenous vegetables, which had been previously reviewed, were made. Focus was to show in pictures the potential micronutrient values of the vegetables and health relevance of the micronutrients. This study did not involve humans hence neither consent nor ethics was required. However, this work was adoption and advancement of ongoing diabetes research in the Delta State Nigeria [2, 3].

\section{RESULTS AND DISCUSSIONS}

Results-graphics designs of the 7 sampled vegetables: All seven images indicate similarities or known values of the various vegetables. Add-on health values are highlighted. Figure 1 shows bitter leaf, which is a shrub and commonly domestic vegetable plant that regenerates naturally. It grows well under full humid and sunlight environmental conditions especially in the African tropical areas such as Nigeria. The leaves are used in Nigeria's famous cuisine, the bitter-leaf soup. Extracts are rich in various phenolic and phytochemical compounds and are exceptionally the richest in folic acids and vitamin $\mathrm{C}$ relative to all other vegetables. The bitterness is 
attributed to be symbolic of its medicinal properties

it is widely used traditionally as a quinine-substitute

in Africa [4].

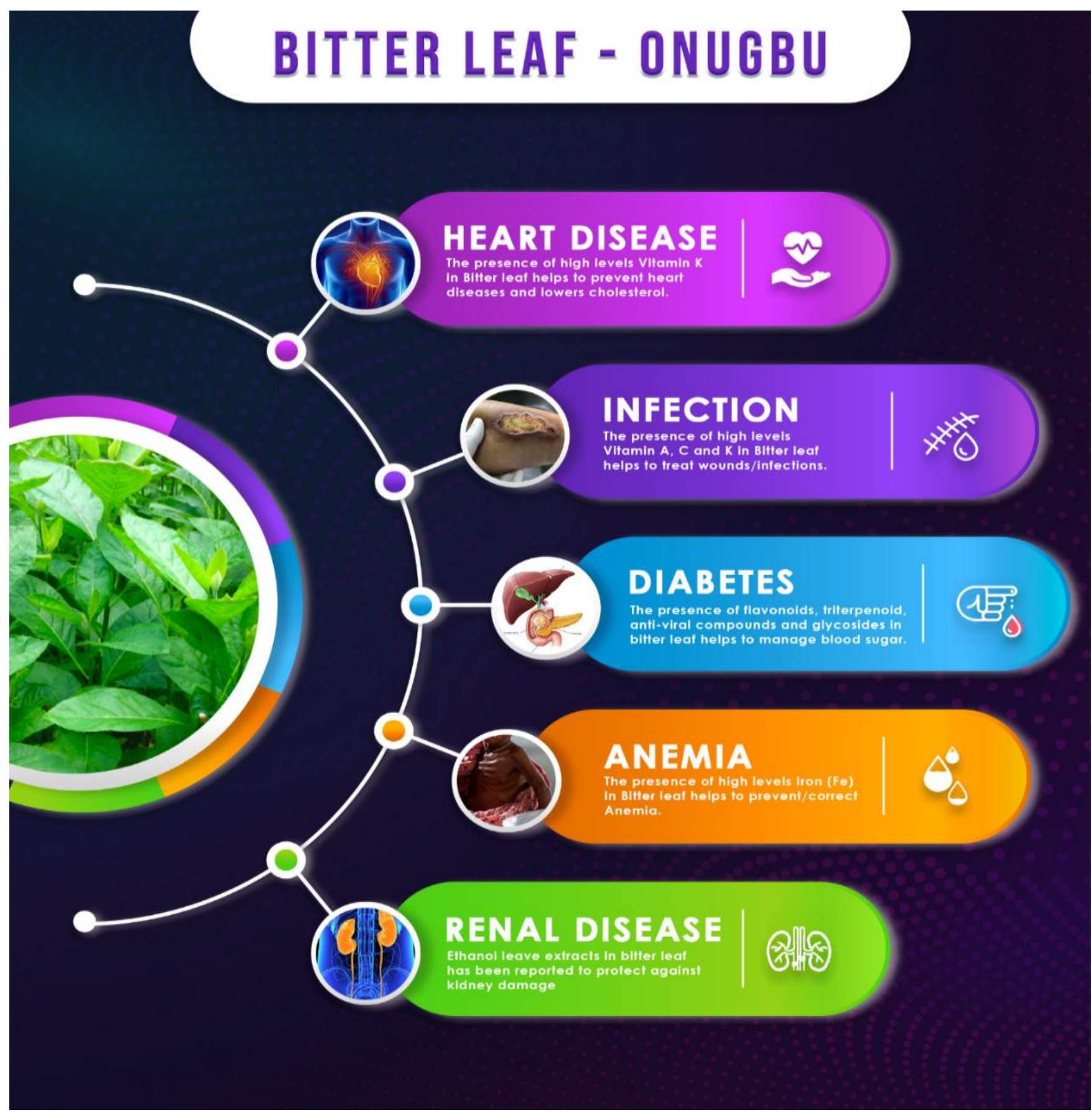

Figure 1. bitter leaf - added value for kidney functions management

Figure 2 shows green amaranth. It grows naturally wild in the farms, though can also be cultivated. Being highly nutritious with high content of antioxidant vitamins $A, C$ and $E$; it has been rated as healthiest in fat content and comparable to bitter leaf, mint leaf and waterleaf in fibers [5]. Due to lack of knowledge, 
this traditionally consumed vegetable is almost now extinct because people don't value it. Yet, the zinc content is valuable in fertility and immunomodulation

[6].

\section{GREEN AMARANTH SHOROKOTOM YOKOTOR}

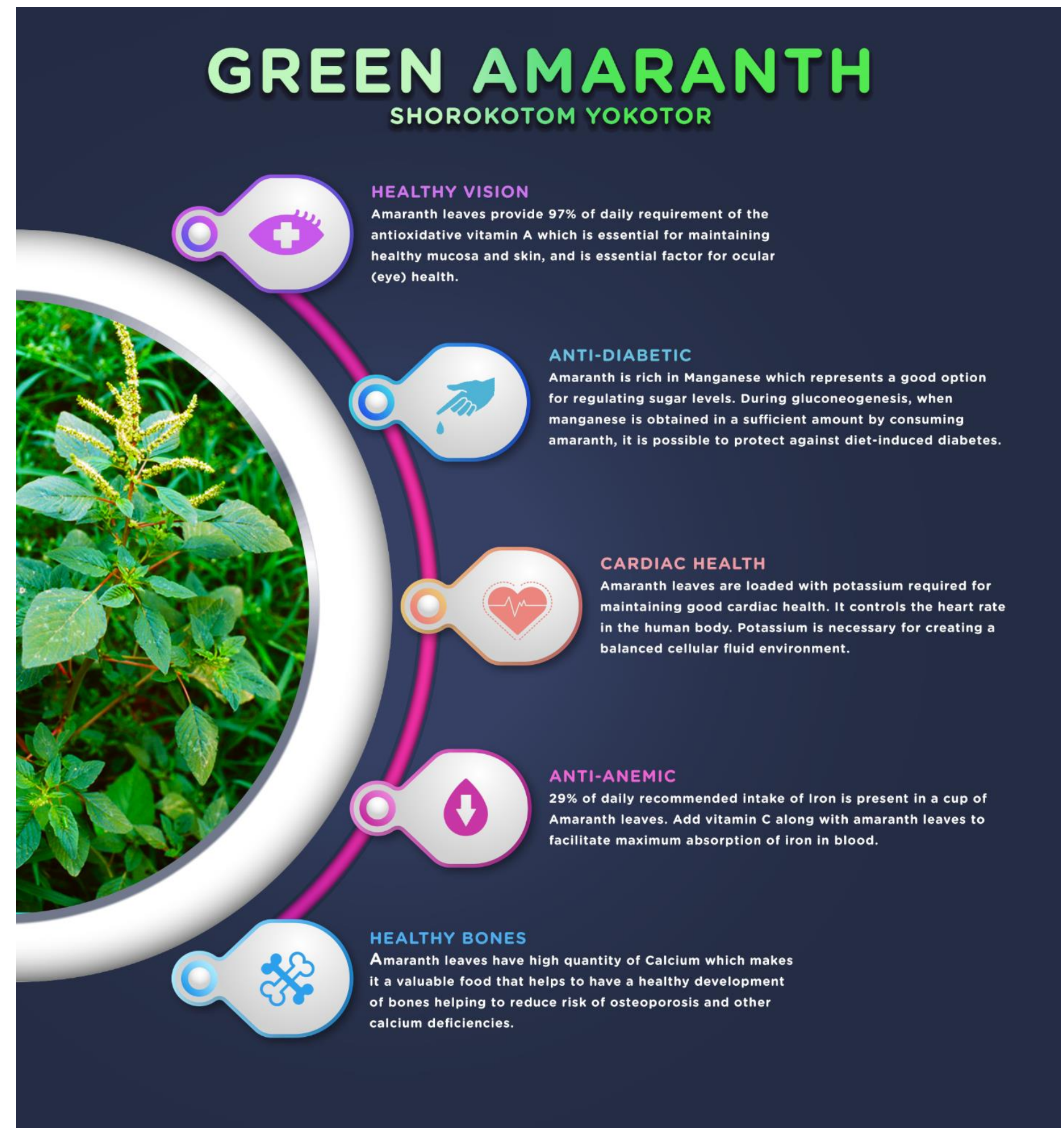

Figure 2. Amaranthus - added value for bone maintenance

Figure 3 is on lemon grass. The vegetable plant can grow naturally, but can also be cultivated e.g. as a cash-crop sold in grocery supermarkets in developed countries. It is indicated to contain more haematinic iron, antioxidant manganese and anti-hypertensive potassium than chives. It is also better than pumpkin leaf in terms of fat/fibre and carbohydrate/fibre ratios [1]. Lemon grass is (i) well appreciated but grossly under-consumed, (ii) used as spices, and (iii) can be consumed in form of herbal infusion tea. 


\section{LEMON GRASS}

\section{ATTA-OYIBO}
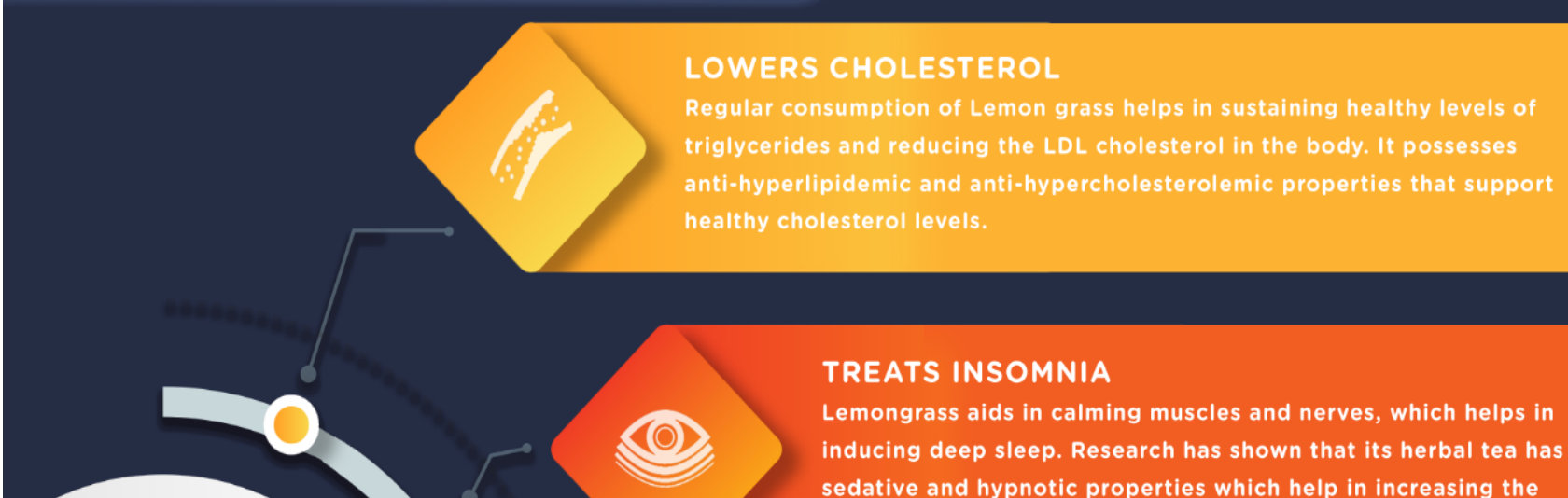

TREATS INSOMNIA

Lemongrass aids in calming muscles and nerves, which helps in inducing deep sleep. Research has shown that its herbal tea has sedative and hypnotic properties which help in increasing the duration of sleep.

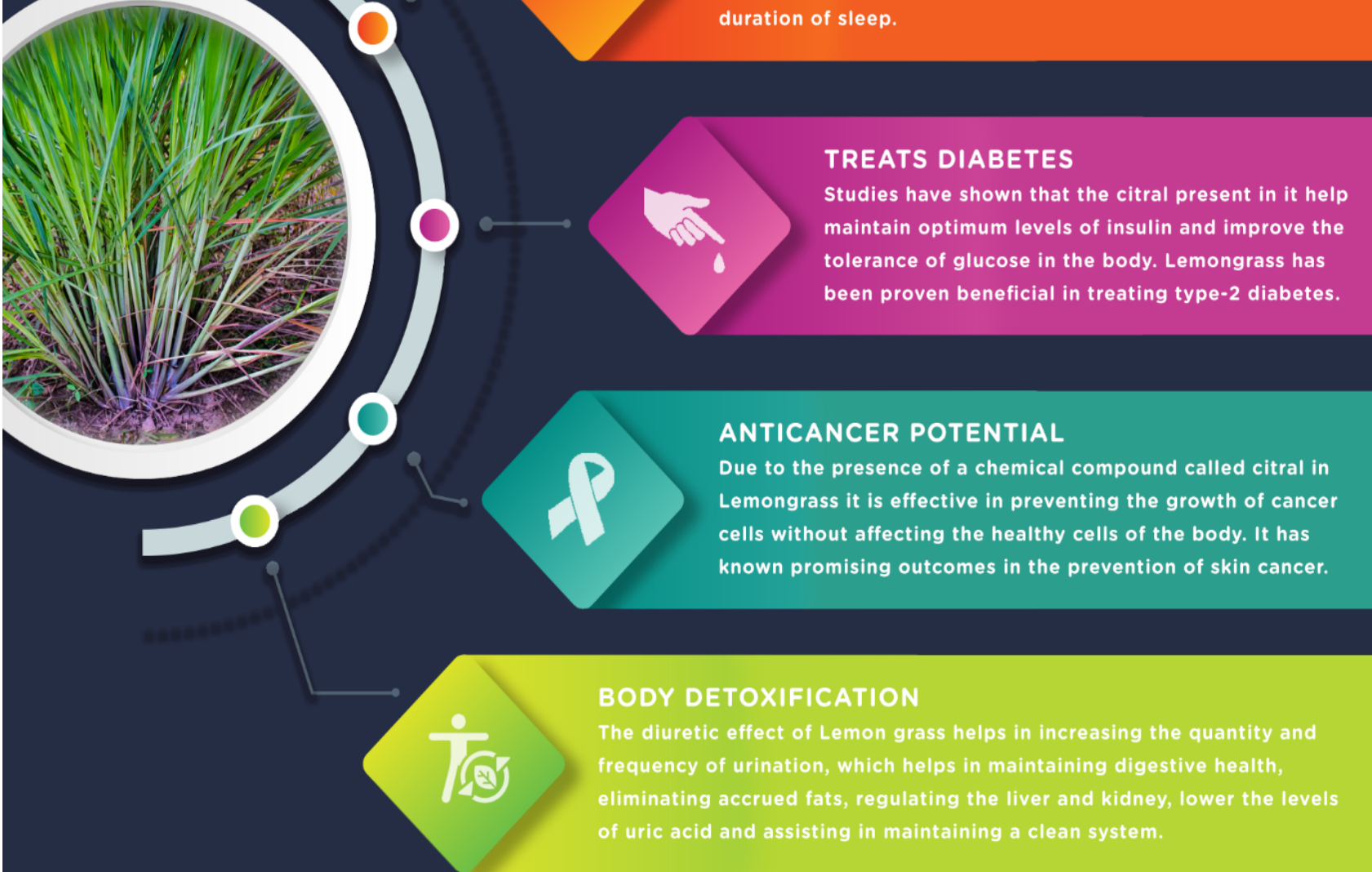

Figure 3. Lemon grass - added value for insomnia management and general detox

Figure 4 is mint leaf. It has the capacity to regenerate, grow wildly and it can be cultivated in domestic vegetable gardens. Mint leaf has a high amount of antioxidant and nutritional values comparable to bitter leaf [7]. Similar to lemon grass, this vegetable is well appreciated but not routinely consumed in the rural communities, except as spices in occasional social delicacies. It is known that consuming it in form of herbal tea infusion can manage several types of illhealth [8]. 


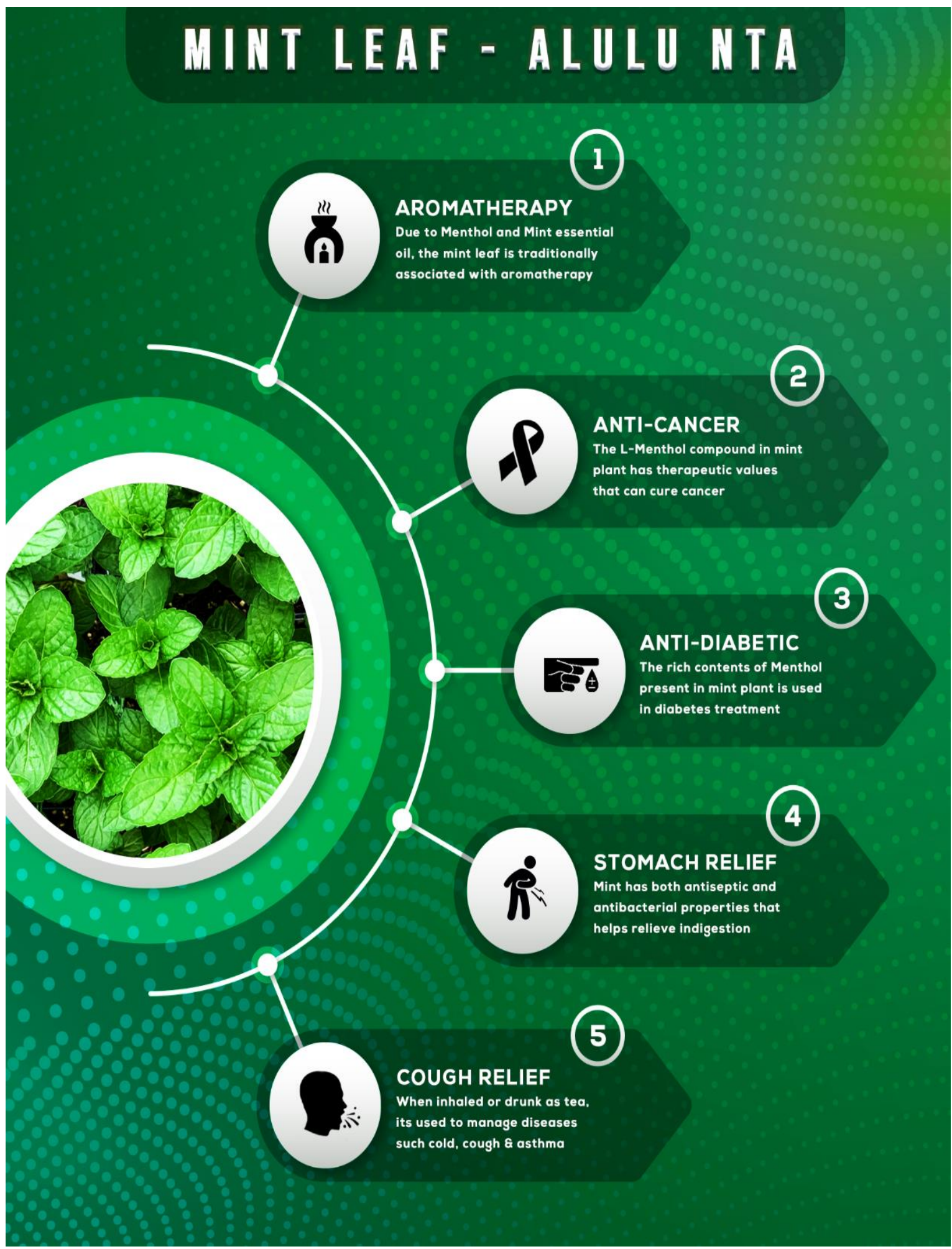

Figure 4. Mint leaf - added value for stomach upset management

Figure 5 graphic is Moringa oleifera. This plant is almost extinguished in the living areas, but still grows wildly as a tree at farm lands. M. oleifera is rated to be richer in vitamin $\mathrm{C}$ than lemon and orange [9]; and the leaves are equally rich in various bioactive compounds including antioxidants. Thus, this is one indigenous vegetable that is yet to be fully appreciated [10]; hence not really eaten by the people. 


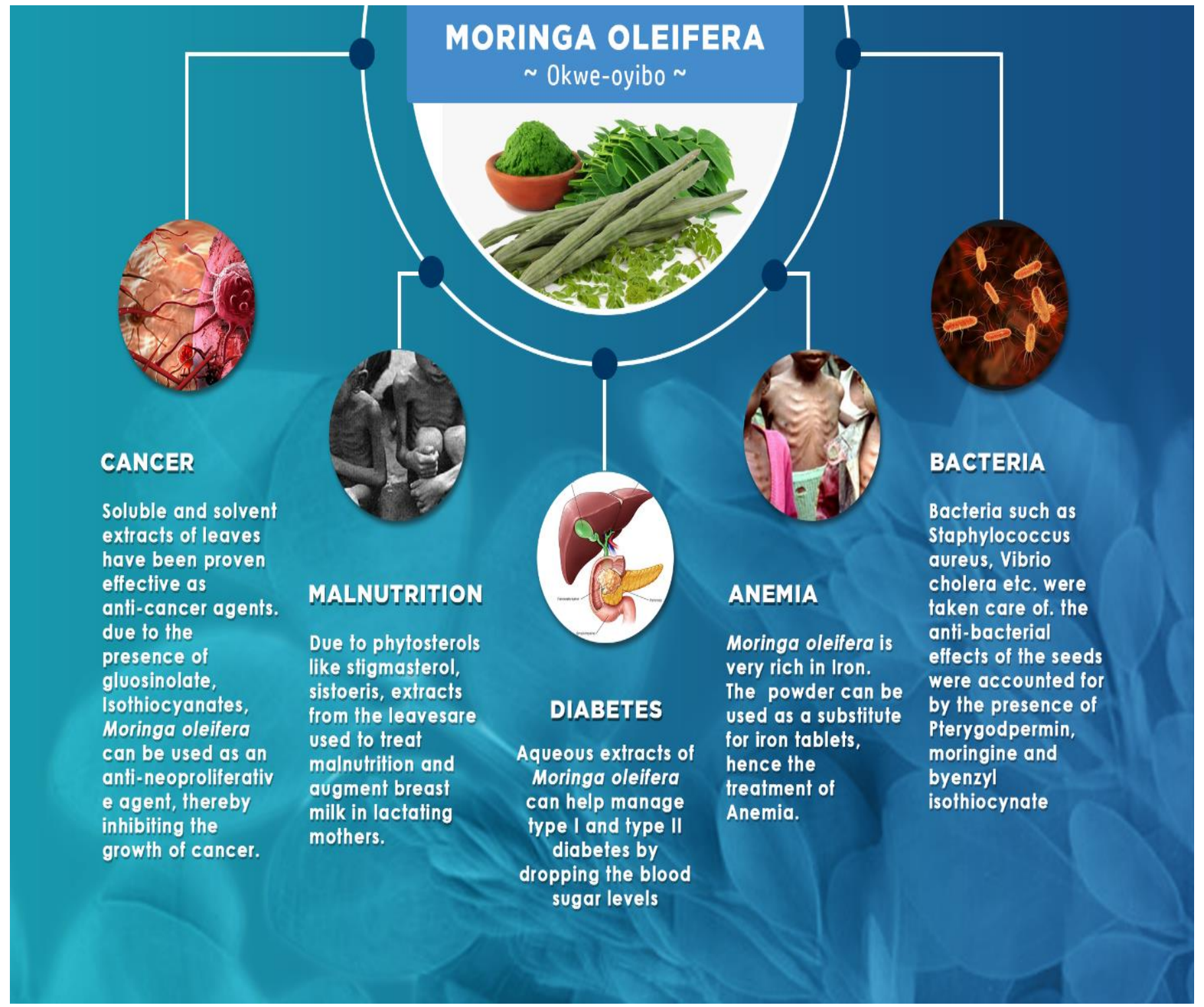

Figure 5. Moringa - added value for cancer and malnutrition management

Figure 6 is the fluted pumpkin (Telfairia occidentalis). It is commonly grown as an outdoor domestic food plant and it is widely cultivated for its nutritious and palatable leaves. The fluted pumpkin is rich in minerals such as $\mathrm{Ca}, \mathrm{P}$, and Fe contents but greatest value is probably the higher content of antihypertensive potassium relative to other commonly consumed leafy vegetable. 


\section{FLUTED PUMPKIN - UGU}

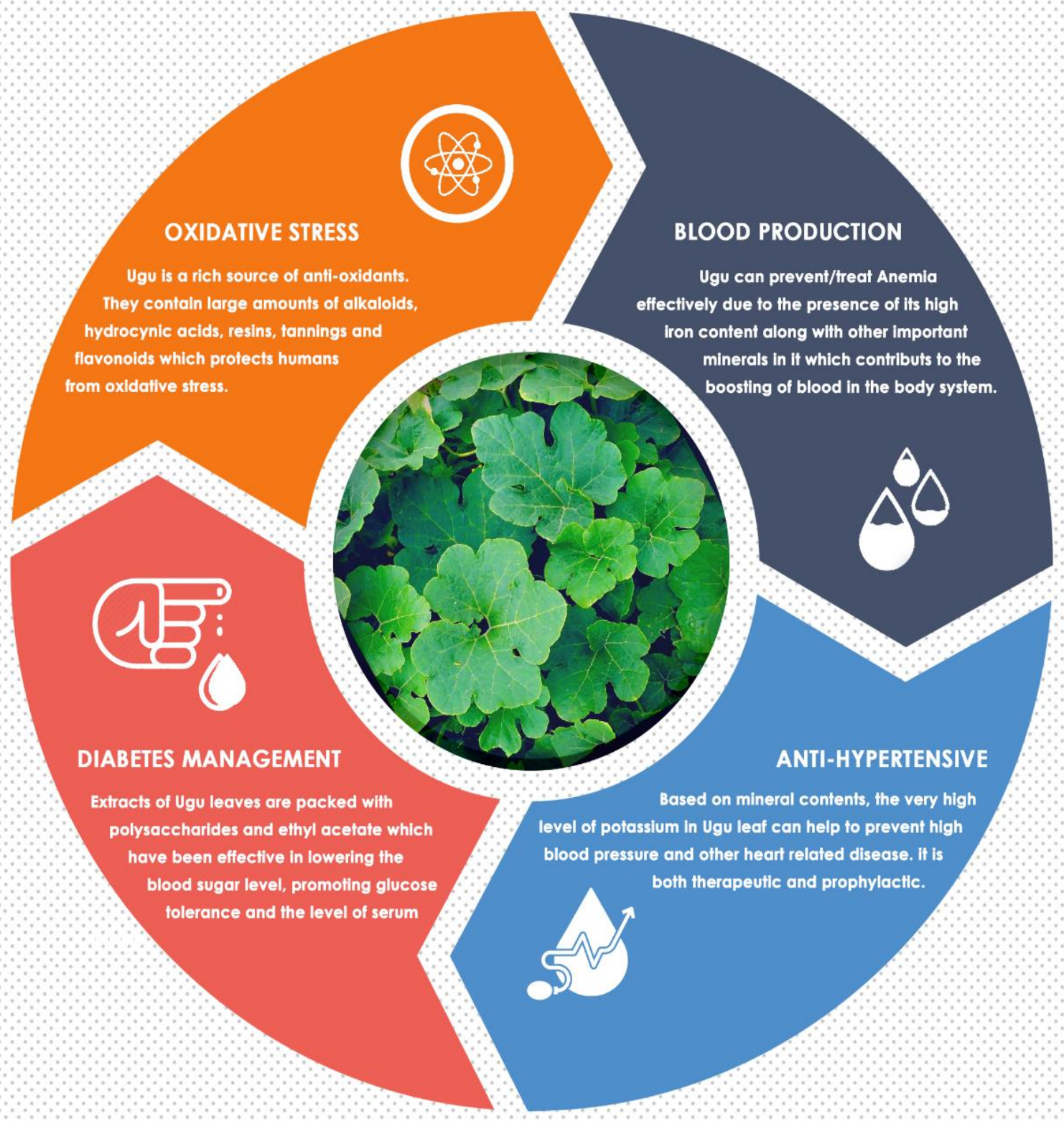

Figure 6. Fluted pumpkin

Last but not the least is water leaf i.e. Talinum triangulare on (Fig 7). Water leaf is known to grow wild on its own even without cultivation. It is rich in fibre, protein and vitamins; besides its food properties. It is a good source of some important minerals such as magnesium and potassium as well as antioxidant vitamins. It is credited to be anti-diabetic, anti-dyslipidaemic and anti-hypertensive (i.e. useful in management of metabolic syndrome) due to the potassium content [11]. Water leaf is easily accessible, much appreciated and commonly consumed. 


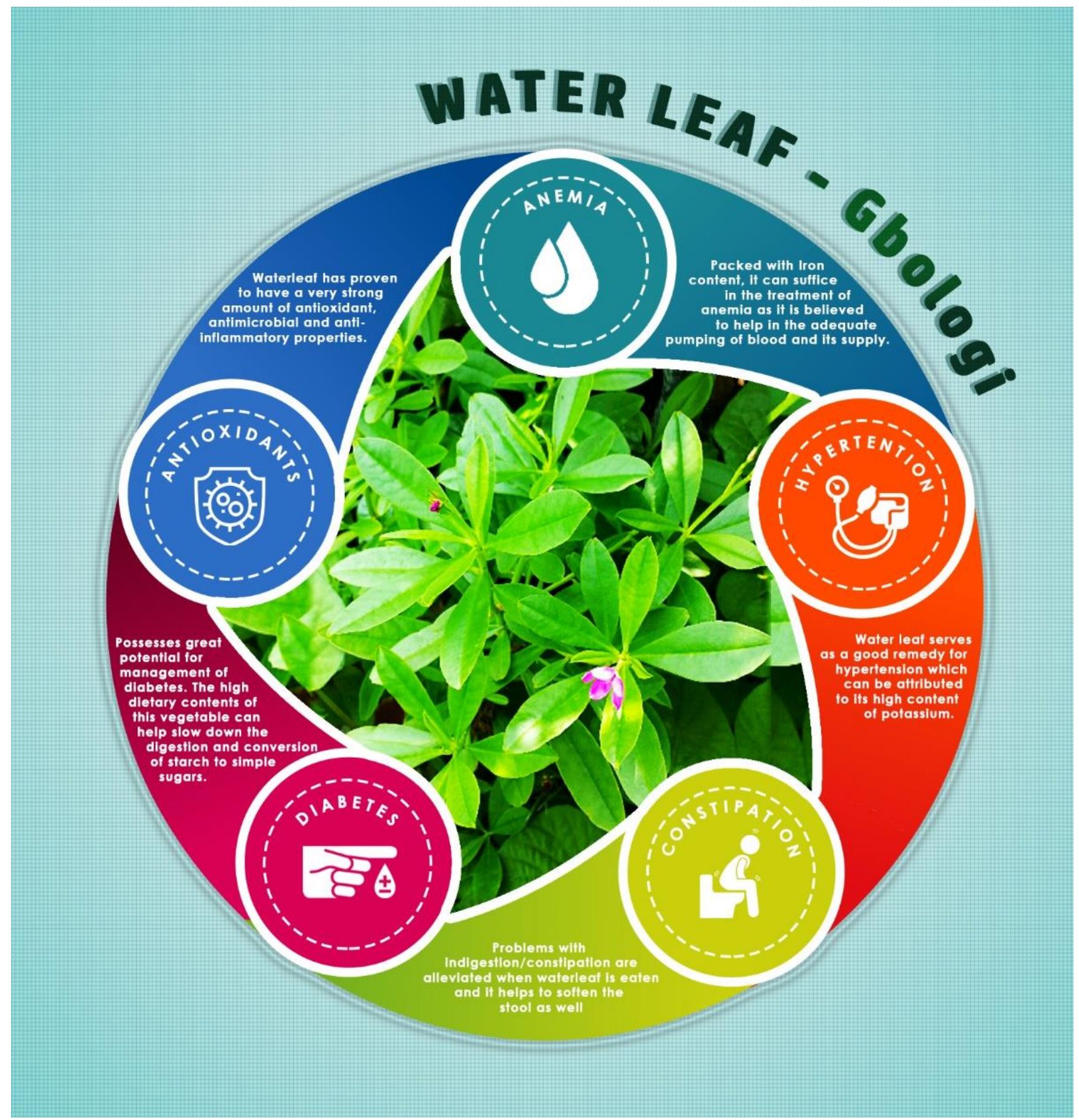

Figure 7. Water leaf - added value for constipation management

\section{Brief note}

Though the research works on the health values of indigenous vegetables abounds, $[5,12-15]$ there is still issue of consumer acceptance that needs to be addressed. It is known that individual's age as well as vegetable's familiarity and taste are among factors associated with taste $[16,17]$.
It is interesting to note that a systematic review of literatures on intervention strategies to improve vegetable consumption indicated there is positive potential for the use of graphics to advance health promotion vis-à-vis intake [17]. However, there is none of such resources on the indigenous vegetables in Ndokwa communities. Therefore, information on the health values of indigenous vegetables in common ailments such as anaemia, metabolic 
syndrome and wound management is relatively scarce. Hence, this piece of work.

Evaluation of graphic designs, just like review of other research manuscripts, can be very subjective [18]. However, there are standard questions for critical qualitative and quantitative evaluations of images [19]. The next phase of this work is to welcome volunteer reviewers to use these standard questions to provide feedback.

In addition, quite pertinent is that it will take more efforts to validate the understanding of messages by different users (age, education, gender groups and environment). This will require dedicated validation studies of the different socioeconomic strata. Therefore, this is a crucial step in the project i.e. to communicate support for the healthy living by consumption of healthy food in a broader setting. Furthermore, there may be cultural or ethical concerns in different populations and places where the designed information is displayed, which may necessitate legal framework (e.g. permission with/without governmental check). One of the agenda in the ongoing work is to investigate these factors that may influence uptake of the educational pictographs. For this, volunteer collaborators are also invited, especially among public health nutritionists and health promotion practitioners.

Implications for the ongoing COVID19 pandemic: Presently, there is an ongoing COVID19 pandemic and complementary medicine including good nutrition is being advanced in the treatment roadmap [20]. Plants are known for their diverse antioxidant potentials. The antioxidants are hematinic [21-23], by their ability to prevent erythrocyte oxidative stress that would otherwise lead to anaemia [20]. For instance, the bioavailability of the iron from vegetables may be lower relative to meat [24]; but there is also the antioxidant potentials of vegetables. Indeed, the World Health Organisation recommends that "Applied to iron deficiency, efforts should be directed towards promoting the availability of, and access to, iron-rich foods. Examples include ... non- animal foods such as legumes and green leafy vegetables" [25].

Oxidative stress reduces (while antioxidants improve) haematocrit [21-23].

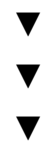

Vegetables reduce oxidative stress, by their antioxidant potentials [23].

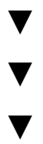

Hence, vegetables indirectly improve haematocrit [25]

Figure 8. Role of vegetables in oxidative stress

Further, antioxidants modulate iron homeostasis [23]. Beyond being haematinics, antioxidants have been identified as having immunomodulatory effects [26]. Also, the ongoing COVID19 pandemic as raised interest on antioxidant potentials copper and zinc $[27,28]$, which are rarely considerable micronutrients in vegetables. It is pertinent to note that all the vegetables presented here have some levels of copper and zinc (Table 1), as evident from authors [29-32].

Table 1: Copper and zinc contents of the vegetables presented

\begin{tabular}{llll}
\hline Source & Vegetable & Copper & Zinc \\
\hline & Bitter leaf $(\mathrm{mg} / \mathrm{kg})$ & 0.2 & 2.87 \\
Onianwa et & Amaranthus $(\mathrm{mg} / \mathrm{kg})$ & 0.07 & 2.87 \\
al (2001) & Pumpkin $(\mathrm{mg} / \mathrm{kg})$ & 0.07 & 3.53 \\
& Waterleaf $(\mathrm{mg} / \mathrm{kg})$ & 0.23 & 2.92 \\
Prkić et al & Mint leaf $(\mathrm{mg} / \mathrm{kg})$ & 3.89 & 7.97 \\
$\begin{array}{l}\text { (2013) } \\
\text { USDA }\end{array}$ & Lemon grass $(\mathrm{mg} / 100 \mathrm{~g})$ & 0.26 & 0.23 \\
$\begin{array}{l}\text { Glover- } \\
\text { Amengor }\end{array}$ & Moringa $(\mathrm{mg} / 100 \mathrm{~g})$ & 5.8 & 21.4 \\
(2016) & & & \\
\hline
\end{tabular}

However, several authors acknowledge the significance of balanced diet for a healthy immune status [33-35]; but lack articulation on the immunemodulatory function of the antioxidant content. 
Hence, this pictorial may help inform the micronutrient value of the indigenous vegetables

\section{CONCLUSION}

This piece of project sets to develop graphical images that would be used as health education resource to promote consumption of indigenous vegetables in Delta State Nigeria. It is first of 2-phased development of the resource. Images of seven vegetables illustrating micronutrient contents that are relevant to anemia, metabolic syndrome and/or wound healing are presented. Voluntary feedback based on objective standard questions are welcomed.

List of abbreviations: COVID19 - coronavirus disease 2019

Competing Interests: There are no conflicts of interest to declare.

Author's Contributions: All the authors contributed to this study. IIC and NEU conceptualized the idea, IIC did the graphics. ES, $\mathrm{CH}$ and IEO are supervising the work contributing to the discussion, NEU did the final draft.

Acknowledgement: IIC is a botanist and his affiliated pathology laboratory is an institutional support base of NEU's diabetes research. This work has been done as an extension of the diabetes self-management peer-education project. The research team at Public and Community Health department of Novena University, Nigeria; as well as the Global Medical Research and Development Organization are here by appreciated for the collaboration.

\section{REFERENCES}

1. Ishiekwene IC, Dada TE, Odoko JO, Nwose EU: Promoting African indigenous vegetables and its medical nutrition properties: A mini-narrative review based on Ukwani communities of Delta State Nigeria. Integr Food Nutr Metab 2019, 6. DOI: 10.15761/IFNM.1000256.

2. Oguoma VM, Nwose EU, Skinner TC, Richards RS, Bwititi PT: Diet and lifestyle habits: Association with cardiovascular disease indices in a Nigerian sub-population. Diabetes Metab Syndr 2018, 12:653-659.

3. Nwose EU, Onokade M, Agofure O, Igumbor EO: Diabetes peer-education on food choices part I: Development of framework Integr Food Nutr Metab 2019, 6.

4. Farombi EO, Owoeye O: Antioxidative and chemopreventive properties of Vernonia amygdalina and Garcinia biflavonoid. Int J Environ Res Public Health 2011, 8:2533-2555.

5. Akinwunmi OA, Omotayo FO: Proximate analysis and nutritive values of ten common vegetables in South-West (Yoruba land) Nigeria. Communications in Applied Sciences 2016, 4:79-91.
6. Adewale A, Olorunju AE: Modulatory of effect of fresh Amaranthus caudatus and Amaranthus hybridus aqueous leaf extracts on detoxify enzymes and micronuclei formation after exposure to sodium arsenite. Pharmacognosy Res 2013, 5:300-305

7. Okunlola GO, Jimoh MA, Olatunji OA, Rufai AB, Omidiran AO: Proximate analysis, mineral composition, and antioxidant properties of bitter leaf and scent leaf. International Journal of Vegetable Science 2019, 25:346-354.

8. Jamila F, Mostafa E: Ethnobotanical survey of medicinal plants used by people in Oriental Morocco to manage various ailments. J Ethnopharmacol 2014, 154:76-87.

9. Mbailao M, Mianpereum T, Albert N: Proximal and elemental composition of Moringa oleifera (Lam) leaves from three regions of Chad. Journal of Food Resource Science 2014, 3:1220.

10. Popoola JO, Obembe OO: Local knowledge, use pattern and geographical distribution of Moringa oleifera Lam. (Moringaceae) in Nigeria. J Ethnopharmacol 2013, 150:682691.

11. Ikewuchi CC, Ikewuchi JC, Ifeanacho MO: Bioactive phytochemicals in an aqueous extract of the leaves of Talinum triangulare. Food Sci Nutr 2016, 5:696-701.

12. Polidori MC, Carrillo JC, Verde PC, Sies H, Siegrist J, Stahl W: Plasma micronutrient status is improved after a 3-month dietary intervention with 5 daily portions of fruits and vegetables: implications for optimal antioxidant levels. Nutr J 2009, 8:10.

13. Andarwulan N, Batari R, Sandrasari DA, Bolling B, Wijaya H: Flavonoid content and antioxidant activity of vegetables from Indonesia. Food Chem 2010, 121:1231-1235.

14. Tsumbu CN, Deby-Dupont G, Tits M, Angenot L, Franck T, Serteyn D, Mouithys-Mickalad A: Antioxidant and antiradical activities of Manihot esculenta Crantz (Euphorbiaceae) leaves and other selected tropical green vegetables investigated on lipoperoxidation and phorbol-12-myristate-13-acetate (PMA) activated monocytes. Nutrients 2011, 3:818-838.

15. Hamer $M$, Chida $Y$ : Intake of fruit, vegetables, and antioxidants and risk of type 2 diabetes: systematic review and meta-analysis. J Hypertension 2007, 25:2361-2369.

16. Gido EO, Ayuya OI, Owuor G, Bokelmann W: Consumer acceptance of leafy African indigenous vegetables: Comparison between rural and urban dwellers. International Journal of Vegetable Science 2017, 23:346-361.

17. Appleton KM, Hemingway A, Saulais L, Dinnella C, Monteleone E, Depezay L, Morizet D, Armando Perez-Cueto FJ, Bevan A, Hartwell $\mathrm{H}$ : Increasing vegetable intakes: rationale and systematic review of published interventions. Eur J Nutr 2016, 55:869-896.

18. Cerger R: How to evaluate the quality of your design [https://99designs.com.au/blog/tips/evaluate-designquality/accessed $13^{\text {th }}$ July, 2020]

19. Unversity of Washington Library: Images: Evaluating Images [https://guides.lib.uw.edu/tac-images accessed $13^{\text {th }}$ July, 2020]

20. Nwose EU, Bwititi PT: Complementary antioxidant medicine in COVID-19 management and the place of haematology evaluation: Brief critical and scoping review-based commentary. Hematol Med Oncol 2020, 5.

21. Al Balushi H, Hannemann A, Rees D, Brewin J, Gibson JS: The effect of antioxidants on the properties of red blood cells from patients with sickle cell anemia. Frontiers in Physiology 2019, 10.

22. Fibach $E$, Dana M: Oxidative stress in paroxysmal nocturnal hemoglobinuria and other conditions of complementmediated hemolysis. Free Radic Biol Med 2015, 88:63-69.

23. Imam MU, Zhang S, Ma J, Wang H, Wang F: Antioxidants mediate both iron homeostasis and oxidative stress. Nutrients 2017, 9.

24. Wells AM, Haub MD, Fluckey J, Williams DK, Chernoff R, Campbell WW: Comparisons of vegetarian and beef- 
containing diets on hematological indexes and iron stores during a period of resistive training in older men. Journal of the American Dietetic Association 2003, 103:594-601.

25. World Health Organization: Iron deficiency anaemia: Assessment, prevention, and control [https://www.who.int/nutrition/publications/en/ida assess ment prevention control.pdf accessed $5^{\text {th }}$ Nov, 2019]

26. Aukrust P, Müller F, Svardal AM, Ueland T, Berge RK, Frøland SS: Disturbed glutathione metabolism and decreased antioxidant levels in human immunodeficiency virus-infected patients during highly active antiretroviral therapy--potential immunomodulatory effects of antioxidants. Journal of Infectious Diseases 2003, 188:232-238.

27. Derbyshire E, Delange J: COVID-19: is there a role for immunonutrition, particularly in the over 65s? BMJ Nutrition, Prevention \&amp;amp; Health 2020:bmjnph-2020-000071.

28. McAuliffe S, Ray S, Fallon E, Bradfield J, Eden T, Kohlmeier M: Dietary micronutrients in the wake of COVID-19: an appraisal of evidence with a focus on high-risk groups and preventative healthcare. BMJ Nutrition, Prevention \&amp;amp; Health 2020:bmjnph-2020-000100.

29. Onianwa PC, Adeyemo AO, Idowu OE, Ogabiela EE: Copper and zinc contents of Nigerian foods and estimates of the adult dietary intakes. Food Chemistry 2001, 72:89-95.

30. Prkić A, Giljanović J, Petričević S, Brkljača $M$, Bralić $M$ : Determination of cadmium, chromium, copper, iron, lead, magnesium, manganese, potassium, and zinc in mint tea leaves by electrothermal atomizer atomic absorption spectrometry in samples purchased at local supermarkets and marketplaces. Analytical Letters 2013, 46:367-378.

31. Glover-Amengor $M$, Aryeetey $R$, Afari $E$, Nyarko A: Micronutrient composition and acceptability of Moringa oleifera leaf-fortified dishes by children in Ada-East district, Ghana. Food Science \& Nutrition 2016, 5:317-323.

32. US Department of Agriculture: Lemon grass (citronella), raw [https://fdc.nal.usda.gov/fdc-app.html\#/fooddetails/168573/nutrients accessed $13^{\text {th }}$ July, 2020]

33. Jayawardena $R$, Sooriyaarachchi $P$, Chourdakis $M$, Jeewandara C, Ranasinghe P: Enhancing immunity in viral infections, with special emphasis on COVID-19: A review. Diabetes \& metabolic syndrome 2020, 14:367-382.

34. BourBour F, Mirzaei Dahka S, Gholamalizadeh M, Akbari ME, Shadnoush M, Haghighi M, Taghvaye-Masoumi H, Ashoori N, Doaei S: Nutrients in prevention, treatment, and management of viral infections; special focus on Coronavirus. Arch Physiol Biochem 2020:1-10.

35. Calder PC, Carr AC, Gombart AF, Eggersdorfer M: Optimal nutritional status for a well-functioning immune sSystem is an important factor to protect against viral infections. Nutrients 2020, 12. 